\title{
An Assessment on Bird's Diversity in Bagmati River Corridor
}

\author{
Saroj Thapa $^{1}$, Shambhu Paude ${ }^{2}$ \\ \& Dipak B.K. ${ }^{3}$
}

\begin{abstract}
Bagmati River is considered as a potential conservation area in terms of the bio-diversity conservation due to its unique and diversified habitat distribution. Due to various causes, the river is being polluted and hence habitat degradation rate is increasing. As a consequence, the direct effect is seen on birds inhabiting there. Aiming the assessment of bird's diversity, one year survey was conducted in Bagmati River from Tilganga Bridge to chobhar Gorge Bridge (here after termed as Bagmati river corridor) by applying the point count method.In the total enumeration, 100 of birds species were recorded among which 7 are listed in CITES appendix. The bird species that are regarded as globally threatened are not recorded in the study area. In this report, some potential patches in the study area, are described as hot spots, considering the higher probability of recording maximum number of birds species. The public voice is also collected to find out the public perception on the present status of birds of Bagmati river corridor using the questionaire method. Some causes of habitat destruction and some potential conservation measures are also mentioned.
\end{abstract}

Key Words: Bagmati river corridor, Birds, Conservation, Hotspots, Diversity, Habitat

\section{Introduction}

Bagmati River and its tributaries are the main source of water in the Kathmandu valley. In the ritual history of Hindus, it is taken as a very sacred river. The Bagmati River and its surroundings (here after termed as Bagmati river corridor) are taken as the richest site for wetland and other winter birds. The population and urbanization rate of the valley is rapidly increasing with time. Due to the direct human influence on the river, it is being polluted and the water discharged is also becoming toxic. As a consequence, the habitat of winter birds and the wetland is degrading. To provide the basic status of bird's diversity in the Bagmati river corridor, this study had been carried out.

\section{Objectives}

The main objective of the study is to find out the birds diversity in the Bagmati river corridor and also to know the major hotspots in the area.

\footnotetext{
Kathmandu Forestry College, Kathmandu, Nepal, crazy_sarose@yahoo.com

2 Kathmandu Forestry College, Kathmandu, Nepal, oasis.excurrent@gmail.com

3 Kathmandu Forestry College, Kathmandu, Nepal, rkbdipak@hotmail.com
} 


\section{Study area and duration}

The study had been carried out in the Bagmati river corridor starting from Tilganga Bridge to Chobhar Gorge Bridge which includes about $13 \mathrm{~km}$ in length. The study had been done for a period of a year starting from 1 November 2006 to 30 October 2007.

\section{Vegetation type in the study area}

Though the Bagmati River channels the fresh water, specific hydrophytes are not distributed. In the study site, there is no such dense vegetation area but small patches of mixed forest with mostly indigenous tree species such as Painyu (prunus ceracoides), Lapsi (choerospondias axillaries), etc are found. However some exotic species such as Bains (Salix species), Gulmohar (delonix regia) and lahare pipal (populas deltoids) etc are also found. Some clumps of bans, reeds, banmara etc. are also found.

\section{Habitat variety}

The Bagmati River itself is the main habitat for birds. Beside this, muddy area of river bank, patches of grass and shrubs, cultivated land near-by and some patches of forest with pine and uttis are the main habitat types found in the study site.

\section{Methodology used}

\section{Surveying Methodology}

The study was completed by point count method. The observation spots were fixed in every span of about $500 \mathrm{~m}$. There were total 26 observations stations in the study area. Metal plates numbering 1 to 26 had been kept in the station. Tilganga Bridge was taken as the first and the Chobhar Gorge Bridge as $26^{\text {th }}$ observation station. The visit was made every fortnight. The total study area was divided in-to three parts (via: part I: station 1-8, part II: station 9-7 and part III: 18-26) and three surveyors observed the birds in each part. All birds seen or heard for 15 minutes were noted down. A pair of binocular and a book "Birds of Nepal" (Grimmett et al. 2000) were used for identifying birds. Unidentified birds were noted for later reference with experts. Survey started each day at 6:30 am and four hours were spent in total in a day giving at least 15 minutes to a station. This enabled one observer to cover all station. Observers swapped stations routinely to minimize biases. The observation speed of observer was uniform. The observation parts divided before were allocated to each surveyor alternately for their visit. Twenty four visits had been done during the study.

\section{Social surveying methodology}

A separate social survey was done by using single questionnaire method to find out the people's response on birds status. The single question: "what is the status of bird in the Bagmati river corridor?" was asked to 40 people, residing near the river. 


\section{Data collection and compilation methodology}

The information obtained from the observation was noted in a field book and compilation was done in monthly basis after the development of a separate field note form, so that the information could be checked in every month. After the monthly compilation, final compilation of information was done.

\section{Limitation}

Due to the weather disturbance, such as fog in winter and rain in monsoon season, some birds might have got excluded from record, but it is assumed that, the excluded bird is recorded the observation that follows.

\section{Findings}

\section{Species record}

A total of 100 bird species were recorded in the study site. Among the species recorded, 7 species are listed in the CITES appendix.

In the case of maximum number of birds observed in a group, are of common birds except black kite which is listed in the CITES appendix II and up to 51 had been recorded in a group during the study. The total enumerated bird list is presented in the annex I. It is noted that, the Birds wetland birds are few in numbers. The main cause of reduction may probably be due to the destruction of suitable habitat.

\section{Species record on the basis of month}

During the survey, the maximum number of bird species was recorded in winter season. More than 50 spps. had been recorded in January, February, March, November and December on each month where as in monsoon season less than 25 had been recorded on each month. It shows that, Bagmati river corridor genuinely may be the special habitat for winter and migratory birds and the number spps. may

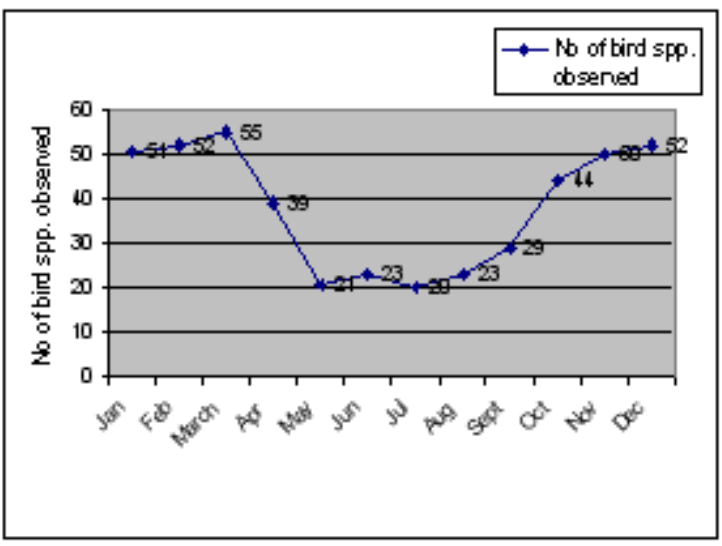

Chart 1: Bird's species recording pattern increase if the habitat is conserved. The detail of the bird's species recorded on the basis of the month is described in chart 1 .

\section{Species record on the basis of frequency}

During the survey, some species were recorded frequently while some were recorded occasionally and some even only once. Among the total number of birds species recorded during 24 visits, five frequent birds and five rare birds were listed. 


\section{Habitat Destruction}

It is clear that the bird's habitat in Bagmati river corridor is highly deteriorated, which is clearly proved by the record of very less population of bird in the site. Following are the main causes of habitat destruction that were observed during the visit of the study area.

- Direct disposal of the garbage in the river

- Direct discharge of the sewage to the river.

- Rapid illegal collection of sand from the river.

- Increasing rate of unplanned urbanization

- Encroachment of the river bank by the landless people for the settlement.

Due to the above mentioned causes, the river bank and even the river water is being highly polluted and toxic. As a consequence, the number of birds is reducing.

\section{Social Surveys}

To find out the peoples response on the birds status in the study area, a single question was asked to 40 people, residing near the river area, and their response was compiled.

\section{Hotspots in the Study Area}

The small patches of either forest or grassland area is included in the study site. The potentiality of maximum number of birds' species can be recorded and these areas are

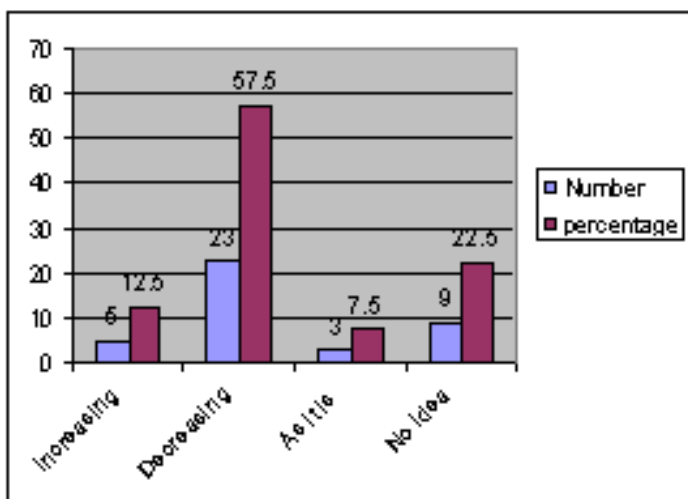

Chart 2: showing the people response defined as the hotspots in the study area. The hotspots identified in the study area are: Between Bagwani suspension bridge to chobhar Gorge Bridge, Between Balkhu Bridge to Teku suspension bridge, Forest patch (nearer to the Teku suspension bridge), Bagmati River Nature Park, and Between Baneshwor campus and SchEmes College.

Beside these areas, the grassland area covering some bushes around the river bank also offers the better habitat for birds.

\section{Conservation Measures /Recommendations}

If the pollution and toxicity in Bagmati river corridor can be reduced, the probability of increasing bird's diversity in terms of both species and number is high under the assumption that the habitat condition will be improved. Bagmati river catchments area is also considered as the potential Important Bird's Area (IBA) (Baral H. S., Inskipp 2005) and probably the study site is included under that. Conservation measures may play vital role in the diversity conservation of the study area. Direct disposal and dumping of urban garbage in the Bagmati River and its bank should managed with the direct coordination of Kathmandu Metropolitan city and Lalitpur sub-metropolitan city, targeting the conservation of Bagmati river bio-diversity. The 
establishment of reed may be an effective biological filtration method as demonstrated in Bagmati River Nature Park (BNP). The Bagmati river nature park (BNP) is the best example of bio-diversity conservation of river. Such model if possible, should be extended all over the corridor. Various awareness approaches should be adopted for Bagmati river corridor conservation. For instance, Bagmati River cleaning campaigns, training, workshops and other extra curricular activities to school students, teachers and city dwellers. Unplanned urbanization, especially nearer to the river bank, should be controlled that the pollution due to disposal of garbage may come under control. Illegal sand collection system from the river should be stopped and the alternative job opportunity to the sand collectors should be managed. Special encouragement to local people along the river should be made for the plantation and conservation of river. Since there are many organizations devoting their effort on Bagmati river conservation, special collaboration with the organization that are launching their program in Bagmati river should be made and collaborative program should be launched for the effective and productive conservation of the river. The Bagmati river corridor should be declared as "Bagmati corridor bird conservation area". The river corridor should be developed as special bird watching area to the urban tourist so that the conservation interest can increase among city dwellers.

\section{Conclusion}

The Bagmati river corridor is the richest area for bird's diversity. Despite that, the river is being polluted. If the river is conserved, not only the bio-diversity will be conserved but also the door for other better earning opportunities like development of bird watching, hiking area to the urban tourists, park establishment etc. can be created. It is sure that only positive impacts will be aroused by conserving the Bagmati River and again it is our choice that, whether we want benefit by conserving the Bagmati River or we are ready to loose the nature's finest creation by neglecting it.

\section{Annex I.}

Birds list recorded in the Bagmati river corridor.

\begin{tabular}{|c|c|c|c|c|c|}
\hline $\begin{array}{l}\mathbf{S . N} \\
1\end{array}$ & $\begin{array}{l}\text { English Name } \\
\text { Ruddy Shelduck }\end{array}$ & $\begin{array}{l}\text { Scientific Name } \\
\text { Tadorna } \\
\text { ferruginea }\end{array}$ & $\begin{array}{l}\mathbf{S . N} \\
52\end{array}$ & $\begin{array}{l}\text { English Name } \\
\text { Dark-throated } \\
\text { Thrush }\end{array}$ & $\begin{array}{l}\text { Scientific Name } \\
\text { Turdus ruficollis }\end{array}$ \\
\hline 2 & Common Teal & Anas crecca & 53 & $\begin{array}{l}\text { Red-throated } \\
\text { Flycatcher }\end{array}$ & Ficedula parva \\
\hline 3 & $\begin{array}{l}\text { Eurisian Wryneck } \\
\text { Blue-throated } \\
\text { Barbet }\end{array}$ & $\begin{array}{l}\text { Jynx torquilla } \\
\text { Megalaima } \\
\text { asiatica }\end{array}$ & $\begin{array}{l}54 \\
55\end{array}$ & $\begin{array}{l}\text { Slaty-backed } \\
\text { Flycatcher } \\
\text { S1aty-blue } \\
\text { Flycatcher }\end{array}$ & $\begin{array}{l}\text { Ficectula hodgsonii } \\
\text { Ficedula tricolor }\end{array}$ \\
\hline $\begin{array}{l}5 \\
6\end{array}$ & $\begin{array}{l}\text { Common H oopoe } \\
\text { White-throated } \\
\text { Kingfisher } \\
\text { Eurasian Cuckoo }\end{array}$ & $\begin{array}{l}\text { Upupa epops } \\
\text { Halcyon } \\
\text { smyrnensis } \\
\text { Cuculus conorus }\end{array}$ & $\begin{array}{l}56 \\
57 \\
58\end{array}$ & $\begin{array}{l}\text { Verditer Flycatcher } \\
\text { Siberian Rubythr oat } \\
\text { White-tailed }\end{array}$ & $\begin{array}{l}\text { Eumyias thalassina } \\
\text { Luscinia calliope } \\
\text { Luscinia pectror al is }\end{array}$ \\
\hline 7 & Eurasian Cuckoo & Cuculus canorus & & $\begin{array}{l}\text { White-tailed } \\
\text { Rubythroat }\end{array}$ & \\
\hline 8 & Indian Cuckoo & $\begin{array}{l}\text { Cuculus } \\
\text { micropterus }\end{array}$ & 59 & $\begin{array}{l}\text { Oriental Magpie } \\
\text { Robin }\end{array}$ & Copsychus scularis \\
\hline
\end{tabular}




\begin{tabular}{|c|c|c|c|c|c|}
\hline 9 & Asian Koel & \begin{tabular}{|l|} 
Eudynamys \\
scolopocea
\end{tabular} & 60 & Hodgsons Redstart & $\begin{array}{l}\text { Phoenicurus } \\
\text { hodgsonii }\end{array}$ \\
\hline 11 & $\begin{array}{l}\text { Rose-ringed } \\
\text { P ar akeet } \\
\text { H ouse Swift }\end{array}$ & $\begin{array}{l}\text { Psittacula } \\
\text { hrameri } \\
\text { Apus affinis }\end{array}$ & 61 & $\begin{array}{l}\text { Blue-fronted } \\
\text { Redstart } \\
\text { Blue-caped Redstart }\end{array}$ & $\begin{array}{l}\text { Phoenicurus frontal is } \\
\text { Phoenicurus } \\
\text { coeruleocephalus }\end{array}$ \\
\hline 13 & $\begin{array}{l}\text { Spotted Owlet } \\
\text { Rock Pigeon }\end{array}$ & $\begin{array}{l}\text { Athene brama } \\
\text { Columbia livia }\end{array}$ & 64 & $\begin{array}{l}\text { White-capped Water } \\
\text { Redstart } \\
\text { Plumbeous Water } \\
\text { Redstart }\end{array}$ & $\begin{array}{l}\text { Chaimarrornis } \\
\text { leucocephalus } \\
\text { Rhyocorris } \\
\text { fuliginosus }\end{array}$ \\
\hline $\begin{array}{l}14 \\
15\end{array}$ & $\begin{array}{l}\text { Oriental Turtle } \\
\text { Dove } \\
\text { Spotted Dove } \\
\text { Eurasian Collared } \\
\text { Dove }\end{array}$ & $\begin{array}{l}\text { Streptopelia } \\
\text { orientalis } \\
\text { Streptopelia } \\
\text { chinensis } \\
\text { Streptopelia } \\
\text { decaocta } \\
\end{array}$ & $\begin{array}{l}66 \\
67\end{array}$ & $\begin{array}{l}\text { Spotted Forktail } \\
\text { Slaty-backed } \\
\text { Forktail } \\
\text { Comm on Stonechat }\end{array}$ & $\begin{array}{l}\text { Enicurus maculatus } \\
\text { Enicurus schistaceus } \\
\text { Saricola torquata }\end{array}$ \\
\hline 18 & $\begin{array}{l}\text { Red Collared D ove } \\
\text { CommonRedshank }\end{array}$ & $\begin{array}{l}\text { Streptopelia } \\
\text { tranquebarica } \\
\text { Tringa totanus } \\
\end{array}$ & 68 & $\begin{array}{l}\text { Pied Bushchat } \\
\text { Grey Bushchat }\end{array}$ & $\begin{array}{l}\text { Saxicola caprata } \\
\text { Saxicola ferrea }\end{array}$ \\
\hline $\begin{array}{l}19 \\
20\end{array}$ & $\begin{array}{l}\text { Common } \\
\text { Greenshank } \\
\text { CommonS andpiper }\end{array}$ & $\begin{array}{l}\text { Tringa } \\
\text { nebularia } \\
\text { Actitis } \\
\text { hypoleusos } \\
\end{array}$ & 70 & $\begin{array}{l}\text { Comm on Myna } \\
\text { Jungle Myna }\end{array}$ & $\begin{array}{l}\text { Acridotheres tristis } \\
\text { Acridotheres fuscus }\end{array}$ \\
\hline $\begin{array}{l}21 \\
22 \\
\end{array}$ & $\begin{array}{l}\text { Green Sandpiper } \\
\text { Wood Sandpiper }\end{array}$ & $\begin{array}{l}\text { Tringa ochropus } \\
\text { Tringa glareola }\end{array}$ & $\begin{array}{l}72 \\
73\end{array}$ & $\begin{array}{l}\text { Wallcreeper } \\
\text { Great Tit }\end{array}$ & $\begin{array}{l}\text { Tichodroma muraria } \\
\text { Parus major }\end{array}$ \\
\hline $\begin{array}{l}23 \\
24\end{array}$ & $\begin{array}{l}\text { Black-winged Stilt } \\
\text { Little-ringed Plover }\end{array}$ & $\begin{array}{l}\text { Himantopus } \\
\text { himartopus } \\
\text { Vanellus dibius }\end{array}$ & 74 & $\begin{array}{l}\text { Black-throated Tit } \\
\text { Nepal H ouse Martin }\end{array}$ & $\begin{array}{l}\text { Aegithalos concinrus } \\
\text { Delichon ripalensis }\end{array}$ \\
\hline 25 & $\begin{array}{l}\text { Grey-headed } \\
\text { Lapwing }\end{array}$ & $\begin{array}{l}\text { Vanellus } \\
\text { cinereas }\end{array}$ & 76 & P1ain Martin & Riparia paludicola \\
\hline $\begin{array}{l}26 \\
27\end{array}$ & $\begin{array}{ll}\text { Redwatt } & \text { led } \\
\text { Lapwing } & \\
\text { River Lapwing } & \end{array}$ & $\begin{array}{l}\text { Vanellus indicus } \\
\text { Vanellus } \\
\text { duvaucelii } \\
\end{array}$ & 77 & $\begin{array}{l}\text { Little F orktail } \\
\text { BarnSwallow }\end{array}$ & $\begin{array}{l}\text { Enicurus scouleria } \\
\text { Hirundo rustica }\end{array}$ \\
\hline $\begin{array}{l}28 \\
29 \\
\end{array}$ & $\begin{array}{l}\text { B1ack Kite } \\
\text { Common Buzzard }\end{array}$ & $\begin{array}{l}\text { Milvus migrans } \\
\text { Buteo buteo }\end{array}$ & $\begin{array}{l}79 \\
80 \\
\end{array}$ & $\begin{array}{l}\text { Red-vented Bulbul } \\
\text { Zitting Cisticola }\end{array}$ & $\begin{array}{l}\text { Pycronotus cafer } \\
\text { Cisticola juncidis }\end{array}$ \\
\hline $\begin{array}{l}30 \\
31\end{array}$ & $\begin{array}{l}\text { Steppe Eagle } \\
\text { Booted Eagle }\end{array}$ & $\begin{array}{l}\text { Aquila } \\
\text { nipalensis } \\
\text { Hier aaetus } \\
\text { permatus } \\
\end{array}$ & 81 & $\begin{array}{l}\text { Comm on Tailorbird } \\
\text { Oriental White Eye }\end{array}$ & $\begin{array}{l}\text { Orthotomus sutorius } \\
\text { Zosterops } \\
\text { palpebrosus }\end{array}$ \\
\hline $\begin{array}{l}32 \\
33\end{array}$ & $\begin{array}{l}\text { Common Kestrel } \\
\text { Peregrine Falcon } \\
\text { Saker F alcon }\end{array}$ & $\begin{array}{l}\text { Falco } \\
\text { tirnunculus } \\
\text { Falco peregrinus } \\
\text { Falco cherrug }\end{array}$ & 84 & $\begin{array}{l}\text { Dusky Warbler } \\
\text { Blyths L eaf Warbler } \\
\text { Humes Warbler }\end{array}$ & $\begin{array}{l}\text { Phylloscopus } \\
\text { fuscatus } \\
\text { Phylloscopus } \\
\text { reguloides } \\
\text { Phylloscopus ismei }\end{array}$ \\
\hline 35 & Great C or mor ant. & $\begin{array}{l}\text { Phalacrocorax } \\
\text { carbo }\end{array}$ & 86 & Greenish Warbler & $\begin{array}{l}\text { Phylloscopus } \\
\text { trochiloides }\end{array}$ \\
\hline 36 & $\begin{array}{l}\text { Little E gret } \\
\text { C attle Egret }\end{array}$ & $\begin{array}{l}\text { Egretta garzeta } \\
\text { Bubulcus ibis }\end{array}$ & 87 & $\begin{array}{l}\text { Grey-throated } \\
\text { Babbler } \\
\text { House Sparrow }\end{array}$ & $\begin{array}{l}\text { Stachyris nigiceps } \\
\text { Passer domesticus }\end{array}$ \\
\hline
\end{tabular}




\begin{tabular}{|c|c|c|c|c|c|}
\hline 38 & $\begin{array}{l}\text { Interme diate Egret } \\
\text { Indian Pond H eron }\end{array}$ & $\begin{array}{l}\text { Mesopohyx } \\
\text { intermedia } \\
\text { Ar deola grayi }\end{array}$ & $\begin{array}{l}89 \\
90 \\
\end{array}$ & $\begin{array}{ll}\text { Eurasian } & \text { Tree } \\
\text { Sparrow } & \\
\text { White Wagtail } & \\
\end{array}$ & $\begin{array}{l}\text { Passer montanus } \\
\text { Motacilla alba }\end{array}$ \\
\hline 40 & Little $\mathrm{H}$ er on & $\begin{array}{l}\text { Butorides } \\
\text { striatus }\end{array}$ & 91 & $\begin{array}{l}\text { White-browed } \\
\text { Wagtail }\end{array}$ & $\begin{array}{l}\text { Motacilla } \\
\text { maderaspatensis }\end{array}$ \\
\hline 41 & $\begin{array}{l}\text { B1ack-crowned } \\
\text { Night Heron }\end{array}$ & $\begin{array}{l}\text { Nycticorax } \\
\text { nycticorax }\end{array}$ & 92 & Yellow Wagtail & Motacilla flava \\
\hline 42 & Gray-backedShrike & $\begin{array}{l}\text { Lanius } \\
\text { tephronotus }\end{array}$ & 93 & Grey Wagtril & Motacilla cinerea \\
\hline 43 & Long-tailed Shrike & Lanius schach & 94 & Tree Pipit & Anthus trivialis \\
\hline 44 & $\begin{array}{l}\text { Redbilled Blue } \\
\text { Magipe }\end{array}$ & $\begin{array}{l}\text { Urocissa } \\
\text { erythrorhyncha }\end{array}$ & 95 & Olive-backed Pipit & Anthus hodgsonii \\
\hline 45 & Rufous Treepie & $\begin{array}{l}\text { Dendrocitta } \\
\text { vagabunda }\end{array}$ & 96 & Rosy Pipit & Anthus roseatus \\
\hline 46 & House Crow & $\begin{array}{l}\text { Corvus } \\
\text { splendens }\end{array}$ & 97 & $\begin{array}{l}\text { Yellow-breasted } \\
\text { Greenfinch }\end{array}$ & Carduelis spinoides \\
\hline 47 & Large-billedCrow & $\begin{array}{l}\text { Corvus } \\
\text { macrorhynchos }\end{array}$ & 98 & Comm on Rosefinch & $\begin{array}{l}\text { Capodacus } \\
\text { erytipinus }\end{array}$ \\
\hline 48 & $\begin{array}{l}\text { Yellow-billed } \\
F \text { antail }\end{array}$ & $\begin{array}{l}\text { Rhipidua } \\
\text { hypoxantha }\end{array}$ & 99 & Red Avadavat & Amandava am andava \\
\hline 49 & Black Drongo & $\begin{array}{l}\text { Dicruous } \\
\text { macrocercus }\end{array}$ & 100 & Grey-breastedPriria & Prinia hodgsonii \\
\hline 50 & $\begin{array}{l}\text { Blue Whistling } \\
\text { Thrush }\end{array}$ & $\begin{array}{l}\text { Myophorus } \\
\text { caeruleus }\end{array}$ & & & \\
\hline 51 & Scaly Thrush & Zoothera dauma & & & \\
\hline
\end{tabular}

\section{References:}

Baral, H.S and Inskipp (2005), Important Bird Areas in Nepal: key sites for conservation, Bird conservation Nepal and birdlife international.

Bird Conservation Nepal (2004), The states of Npals bird, Lazinmpat, Kathmandu

Birdlife International (2001), Threatened birds of Asia: Birdlife International Red Data book, birdlife international Cambridge, UK.

Chapagain, Diwakar and janardan dhakal (2002), Nepal ma CITES karyanyaon: 139-142 With reference to Kashmir and Sikkim .Fourth impression .Adarsh books, India.

Grimmet, Richard, C.Inskipp, T, Inskipp and Baral, H.S (2003).Birds of Nepal Christopher Helm, London, UK.

IUCN 2007, 2007 IUCN Red List of Threatened Species.

Riessen, ArendVan (2007) the Birds of Sainbu, Bagmati and Taudaha.2004-2006Danphe16 (2):1-7

Suwal, R.N (1997), Checklist of Nepalese Wetlands Birds IUCN Nepal 